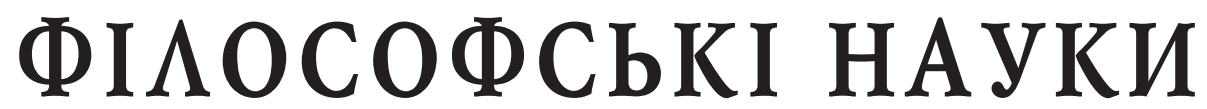

DOI: https://doi.org/10.32839/2304-5809/2021-3-91-10

УДК 1(091)

Павлишин Л.Г.

Тернопільський національний педагогічний університет імені Володимира Гнатюка

\section{ІСТОРИЧНІ ОСНОВИ ПРОБЛЕМИ СЕНСУ ЖИТТЯ У ФІЛОСОФСЬКИХ ПОГЛЯДАХ Ф. НІЦШЕ}

\begin{abstract}
Анотація. Уявлення про сенс життя передбачає життево необхідну мету, а не просто теоретичне поняття. Сенс життя неможливий без важливих цінностей, які є найвищою метою існування людини, їі бажань, мрій та діянь. Та чи інша епоха вносила щось своє у розуміння суті цінностей, а отже, і людина, в свою чергу, відчувала на собі вплив духу певного історичного періоду, в якому вона жила та творила. На думку М. Гартмана, цінності існують у світі вічно, ми можемо їх осягнути апріорно завдяки феноменологічному спогляданню. Ніцше зумів побачити феноменологічну низку цінностей, яким людство ще не надало фрілософського осмислення, хоча й вже носило у собі. Людина завжди відчувала відповідальність перед собою і оточуючим світом, піклувалася про своїх дітей та онуків, тому цінності, на які вказував Ніцше, на думку М. Гартмана, лише доповнюють надбання попередньої історії людства. Ніщше вказував на те, що існують також цінності, які не мають нічого спільного із християнською мораллю. У кожної особистості $€$ уявлення про сенс, адже кожна людина - унікальна. Сенс життя потрібно невпинно переживати щодня. Жити, не знаючи та не розуміючи для чого ми тут, на Землі, неможливо, тому першочерговим завданням для кожного з нас є пошук сенсу існування. Подібні думки тривожили серця мислителів багатьох епох. На думку Ніщше, людина повинна стати творцем самої себе. Високе завдання людини полягає у тому, щоб бути цілісною індивідуальністю, продемонструвати стиль свого характеру, дати художній вияв своїй особистості - в пізнанні і любові, в спогляданні та діяльності.
\end{abstract}

Ключові слова: сенс життя, свобода, людина, задоволення, цінності, світ, мета.

Pavlyshyn Liudmyla

Ternopil Volodymyr Hnatyuk National Pedagogical University

\section{HISTORICAL FOUNDATIONS OF THE PROBLEM OF MEANING OF LIFE IN THE PHILOSOPHICAL VIEWS OF F. NIETZSCHE}

Summary. The idea of the meaning of life involves a vital goal, not just a theoretical concept. The meaning of life is impossible without important values that are the ultimate goal of a person's existence, his desires, dreams and actions. One or another epoch brought something of its own to the understanding of the essence of values and therefore, man, in turn, felt the influence of the spirit of a certain historical period in which he lived and created. According to M. Hartman, values exist in the world forever, we can comprehend them a priori through phenomenological contemplation. Nietzsche was able to see a phenomenal series of values that humanity has not yet provided philosophical comprehension, although it has already worn within itself. Man has always felt a responsibility to himself and the world around him, took care of his children and grandchildren, so the values that Nietzsche pointed out, according to M. Hartman, only complement the achievements of the previous history of mankind. Nietzsche pointed out that there are also values that have nothing to do with Christian morality. The article examines the specifics of F. Nietzsche's interpretation of the meaning of life as a problem. Each individual has an idea of meaning, because each person is unique. The meaning of life needs to be relentlessly experienced every day. It is impossible to live without knowing or understanding what we live for, so the primary task for each of us is to find the meaning of existence. Such thoughts have alarmed the hearts of thinkers of many eras. According to Nietzsche, man must become the creator of himself. The high task of a person is to be an integral individual, to give style to his character, to give an artistic manifestation of his personality - in knowledge and love, in contemplation and activity.

Keywords: meaning of life, freedom, man, pleasure, values, world, purpose.

$\Pi$ остановка проблеми. У кожної особистості є уявлення про сенс, адже кожна людина - унікальна. Жити, не знаючи та не розуміючи для чого ми живемо, неможливо, тому першочерговим завданням для кожного 3 нас $є$ пошук сенсу існування. На думку А. Ейнштейна, людина не зможе жити з відчуттям відсутності сенсу у їі житті. Сенс життя неможливо купити, винайти чи одержати у спадок, його потрібно невпинно переживати щодня. I ніхто не дасть нам гарантій, що щі пошуки будуть легкими та позбавленими перешкод та розчарувань. Проте це буде наш шлях, наші прагнення, які допоможуть зрозуміти для чого ми прийшли у цей світ.

Аналіз останніх досліджень і публікацій. Дана проблематика перебуває у полі зору багатьох дослідників, серед яких Н. Смельянова, I. Ярославцева, А. Лаврова, Г. Камбал, Т. Лютий, I. Силуянова; стосовно етики Ніщше писав свої дослідження С. І. Шаповал.

Наукова новизна. У дослідженні вивчається специфіка трактування Ф. Ніцше сенсу життя як проблеми. Метою статті $є$ аналіз сутності сенсу життя як проблеми у фрілософрії Ф. Ніщше. 
Виклад основного матеріалу. У далеку Античну епоху, міркуючи над проблемою сенсу життя, мислителі прагнули осягнути призначення людини у світі. Демокріт та Епікур справжній сенс життя вбачали у прагненні до задоволення. На думку Демокріта, людина нічим не обмежена, перед нею відкритий увесь світ, для неї немає ніяких меж. Людина мае всі шанси та можливості для свого удосконалення. Мета життя полягає у відчутті доброго стану духу. Демокріт вважав, що ця мета є спільною і для старих, і для молодих. традиціоналізм, релігійна антропологія, герменевтика, філософський символізм. Кіренаїки, зокрема, Арістіпп, Федор, Гегесій, вважали, що мета життя людини - насолоджуватись теперішнім. Свобода була засобом для досягнення щастя. Саме завдяки їй людина зможе у певні моменти свого життя відмовитись від задоволення, яке неможливо досягнути. Свобода здатна полегшити страждання, спричинені недосяжністю бажаних задоволень. Пошук людиною сенсу життя не припинявся в епоху еллінізму. На першому плані опинились проблеми етики, а саме: щастя та призначення людини у світі. Мислителі елліністичного періоду стояли на індивідуалістичних позиціях. Необхідною умовою доброчесного життя, на думку тогочасних мудреців, був відхід від політичної та громадської діяльності. Людина, стаючи розумною істотою, все-таки не перестає залишатись твариною, в якій продовжують діяти інстинкти тварини. Людина буде завжди прагнути їх задовольнити.

У епоху Просвітництва сенс життя полягав у служінні загальному благу, внесенні особистого вкладу в історію, культуру та прогрес суспільства. Але ця ідея не простий заклик розчинити себе у загальному благу. Потрібно знайти ту міру особистого та загального, за допомогою якої можна подолати дві крайні життеві настанови: самозречення особи та ії самоствердження. На таких позиціях стояли релігійні філософи Володимир Соловйов та Семен Франк. Франк підкреслював, що служіння навіть абсолютному началу, яке не прикрашае i не зігрівае власне життя людини, не може надати йому сенсу. Проте лише благо в суб'єктивному значенні також не даруе сенсу, тому що навіть щасливе життя отруене болючим питанням «навіщо?». Люди хочуть заповнити душевну пустку, прагнуть осмисленого та самодостатнього життя. Прийшла пора для того, щоб людина, нарешті, поставила перед собою мету, «настав час, щоб людина посадила паросток своеі надії» $[1$, c. 11]. Вище благо не може бути життям як безглуздим процесом. Ідея загального блага переходить у принцип самоцінності життя як основи вирішення про його сенс. На думку Григорія Сковороди, Людвіга Фейербаха, Еріха Фромма, сенс життя полягає у любові, сердечному почутті, у тому, щоб з любов’ю ставитись до світу. Семен Франк вважав, що любов не $є$ холодним прагненням насолоди, не рабським служінням. Любов - це подолання людського корисного особистого життя, яке дарує блаженну повноту справжнього життя і таким чином надае йому сенсу. Благо любові є благом життя через подолання суперечності між моїм та чужким, суб̆'єктивним та об̆єктивним.

Принцип самоцінності життя у різних фрілософрскких напрямках має різне значення. Імма- нуїл Кант, Федір Достоєвський підкреслювали його моральну сторону. Володимир Соловйов зазначав, що людина ні за яких умов не може бути лише засобом чи знаряддям для блага іншої особи. Ця ідея стала основним принципом сучасного гуманізму. Питання самоцінності життя повинно бути доповнене принципом його самоцільності. На думку Семена Франка, емпіричне життя 3 його швидкоплинністю та неминучими труднощами не може бути самоціллю. Тому осмисленість полягає саме в тому, щоб зупинити безглузду гонитву за самим життям, марнуванням його для нього самого. Потрібно віддавати його заради чогось вищого, що має виправдання у самому собі. Семен Франк розвивае властиву для релігійної фрілософрії та ідеалізму ідею про необхідність Абсолютного блага для обгрунтування осмисленості життя.

На думку Канта, сенс життя людини існуе не сам по собі, а в усвідомленні нею свого буття як людського. Шеллінг, на відміну від Канта, переконаний, що людина не може визначити свій сенс життя тому, що за неї це робить Бог. Шеллінг говорив, що свобода за Кантом полягає у свободі творити добро. 3 цього випливає, що це ніяка не свобода, адже дійсно вільна людина має право бути вільною як у творенні добра, так і зла, у виборі розуму чи абсурду. Й. Фіхте сенс життя людини бачить у гармонії з собою, у її вдосконаленні шляхом постійної праці над собою і світом. Для Гегеля сенс життя пов'язаний із діалектикою світового процесу, він індивідуальний.

Завдяки роздумуванням про сенс можна виділити певні шляхи надання життю сенсу. Віктор Франкл, засновник сучасної логопедії, виділяе такі можливі шляхи: по-перше, це те, що людина дає світу; по-друге, це те, що людина бере від світу; по-трете, те, як вона ставиться до життя. Відповідно до того виокремлюють три групи смисложиттевих цінностей: цінності творчі, цінності переживання, цінності відносин. Цінності ставлення людина реалізуе тоді, коли потрапляе у трагічні обставини, які їй не під силу змінити. Саме такі цінності дозволяють їй прояснити не тільки сенс життя в цілому, але й конкретні життеві ситуації, не втратити сенс життя навіть перед стражданнями та тяжкими життевими випробуваннями.

Уся фрілософрія Ніцше $е$ нічим іншим як запереченням сенсу життя і разом з тим безперервною тривогою і відчайдушними пошуками цього ж сенсу, боротьбою між запереченням розуму і вірою в його силу. Ніщше хотів сповістити людству, що можна віднайти нове джерело надії та радості. Він з усіх сил намагався подолати відчай та песимізм, кидаючи у вічі своїх сучасників зухвалий виклик, таким чином змушуючи замислитись над його ідеями та думками. У філософрії Ніцше простежуеться разом із незадоволенням тогочасним станом суспільства невимовна тривога за майбутне. На думку Ніцше, у тогочасному суспільстві «воля до ніщо стала володаркою над волею до життя» [2, с. 178]. Впродовж століть слова і погляди цього мислителя звучать як пророцтво і застереження, що фральшиві цінності, які сприймаються як належні, можуть зіграти 3 нами злий жарт. I тоді ми, не маючи ні змоги, ні бажання розмежувати правду і обман, візьмемо собі в якості путівника по життю усе те, з чим 
так наполегливо та не знаючи спочинку боровся цей скромний геній. Цілком зрозумілим є те, що Ніцше як вдумливий і оригінальний мислитель звернув свою увагу на масштабне за своєю значущістю явище тогочасної культурної Свропи - декаданс, 3 наслідками якого він боровся до кінця свого життя. Духовну кризу тогочасного суспільства Ніцше передчував одним з перших ще у XIX столітті. «Панівні класи, для яких він говорив і писав, ще не відчули духовної пустки, їхні ідеали ще не пройнялися відчаєм, песимізмом і безперспективністю існування» [3, с.129]. Його фрілософрія - це прагнення до нового ідеалу, що був сенсом та метою життя. Ім'я цього загадкового ідеалу - надлюдина. Сила і могутність, розум та інтелект, воля та гордість - далеко не всі характеристики цієї людини нового типу. На думку Ніщше, мета людства полягає не в кінці історії людського роду, а тільки в його вищих представниках. Надлюдина - надія та ідеал людини.

Ідеї та думки Ніџше глибоко вкорінились у думках і серцях його сучасників, які, не залишаючись байдужими до проблем тогочасного суспільства, продовжували справу Ніщше. Були й ті, послідовниками котрих був і він сам. Погляди Артура Шопенгауера мали велике значення у формуванні фрілософрських поглядів майбутнього творця моралі нового типу. Також Яків Буркхардт мав великий вплив на формування поглядів молодого Ніщше. Буркхардт був також глибоко розчарований станом тогочасного суспільства. Проте не тільки в Німеччині відчули його занепад. Відгомін ціеї руйнації лунав і у інших країнах. Падіння моралі важко переживали Г. Лебон у Франції, Ч. Пірс у США, В. Соловйов у Росії.

Життя повинно проходити під знаком боротьби за силу духу. Сучасники Ніщше не зрозуміли справжньої суті моралі, бо якщо б було по-іншому, то вони б побачили, що потрібно встановити іншу, бойову мораль, мораль хороброго змагання. Ось що Ніцше називає природними, істинними цінностями. А тому не можна погодитися 3 думкою, що «людина для нього - це духовний рух «по колу», без мети, що веде до постійного повернення» [4, с. 127]. Ніщше вважав себе загубленим у пустелі епохи християнства. Він так важко шукав дорогу у ті часи, коли життя і сила духу, велич і краса людини вважались законом існування. Ніцше представляе собою один із останніх відгомонів доби Фулье, Ренана, Фейєрбаха, Гейне, Шопенгауера. Коли він починає говорити, то чути голоси грецьких codpicтів та скептиків, Макіавелі, Гобса, Гельвеція, Дідро, Штірнера, Бакуніна, Кропоткіна - всі голоси останніх епох. Для Ніцше традиційна мораль - небезпечна і отруйна. Через неї людство не змогло досягнути більшого прогресу. Ніхто ще не наважувався підривати основи моралі, щоб закласти фрундамент нової. Не так вже це просто зробити перший крок до руйнування того, що було звичним і прийнятним. Ніщше не боявся осуду оточуючих і наважився завдати нищівного удару по тогочасних законах моралі. Усе, що шанувалося до того часу, стає таким, що потрібно переглянути, відкинути і змінити. Людина із давніх-давен замислювалась над тим, як їй слід жити, як поводитись у суспільстві, як чинити із своїми ближніми.
Доля Ф. Ніцше містила драматизм перехідної епохи на межі XIX-XX століть. Він є одночасно i уособленням всіеї західноевропейської фрілософрської традиції, і першим декадентом. У своїй роботі «Народження трагедії з духу музики» Ніцше говорить про руйнівну дію науки та розуму щодо життя. На ранніх етапах розвитку людства лише мистецтво, на думку Ніцше, зіграло набагато важливішу, порівняно з наукою, роль в житті суспільства. Саме мистецтво є втіленням справжнього життя, стихійним, нічим необмеженим, окрім волі та інстинктів. «Народження трагедії 3 духу музики» - це своєрідний ключ, за допомогою якого можна розкрити таємницю усіеї творчої діяльності мислителя. У цій праці сфрормована основна проблема фрілософії Ніщше, яка буде цілковито втілена у книзі «Так казав Заратустра", а саме: яким чином створити таку культуру, яка змогла б допомогти людині збагатити свій внутрішній світ та удосконалити себе. Проте оптимізм Ніцше почав плавно згасати через невизнання його роботи, крах ідеалів, хворобу. Ніщше, надовго залишаючись наодинці зі своїми роздумами, проблемами, переживаннями, продовжував творити.

На думку С. Франка, «Людське, надто людське» є першою книгою, де Ніцше виступив як нігіліст. До написання цього твору його спонукала духовна криза, причиною якої було розчарування у метафізиці Шопенгауера та розрив 3 його товаришем Вагнером. Ніщше заперечує традиційні цінності. Він піддає нищівній критиці ідеалізм, цінності християнської культури.

У праці «Так казав Заратустра» автор устами Заратустри звертався до своїх сучасників з палкими промовами, за допомогою яких читачі могли ознайомитись з основною ідеєю мислителя - його величним ідеалом, що зветься «надлюдина». Мріючи про неї, Ніцше вважав, що в одній людині будуть мирно вживатись найрізноманітніші сили, що б'ють через край.

Свою працю «По той бік добра і зла» Ніцше вважав продовженням теми, розпочатої у «Заратустрі». «По той бік добра i зла» - це трагічний i водночас пророчий твір. Його тема є актуальною і на сьогоднішній день. Ніцше зобразив цілу низку загальнолюдських проблем, а саме: нівелювання людини, занепад духовності, втрату людиною власної індивідуальності. Ніцше зумів показати, яку небезпеку поряд з науково-технічним прогресом приховує цивілізація. У праці «До генеалогії моралі» Ніцше продовжуе роздумувати над походженням та сутністю моралі, розглядати її як феномен, що повністю зумовлений фракторами розвитку людини. У даному творі фpiгурують три основні проблеми, а саме: аскетичні ідеали, що здатні наповнити людське життя сенсом, "нечиста совість» як джерело жорстокості, i, нарешті, - ressentiment, що є визначальним поняттям у структурі моральних цінностей. Цей термін характеризує стан ненависті та злоби у сукупності з відчуттям безсилля, що виникає у людини, коли їі внутрішній світ не перебуває у гармонії з оточуючим середовищем.

На належну увагу заслуговуе праця Ніцше «Сутінки ідолів, або Як філософрують молотом», у якій автор висвітлюе основні засади своїх поглядів на світ. Філософ, неначе озираючись на- 
зад, аналізуе свій духовний світ і готуе грунт для наступних творів. Цими працями стали "Антихрист» та «Воля до влади». Ніцше гнівно висловлюється на адресу християнства як такого, що перешкоджає гармонійному розвитку сильних людей, основними характеристиками яких $\epsilon$ «воля до влади», сила, природні інстинкти, нічим та ніким не обмежені. Основні ідеї своєї книги Ніцше представив у чотирьох тезах. Поперше, є помилкою поділяти світ на реальний i той, що існує поза реальністю. По-друге - думати про інший світ немає ніякого сенсу. По-третє світ поза межами нашої реальності є лише морально-оптичним обманом. По-четверте - інший вид реальності довести неможливо. Піддаючи різкій критиці християнство, Ніцше вказував на те, що духовенство тішить людей обіцянками про щасливе вічне життя у потойбічному світі, проповідуючи покору та смиренність, відбирає у людини віру у себе, свої можливості та здатність об'єктивно оцінювати реальний світ. Заперечуючи Бога, Ніцше прагнув довести собі, своїм сучасникам та прийдешнім поколінням, що у нього є та сила духу, яка допомагає йому жити без допомоги Бога та надій на нього. Важко було 6 відшукати ще одного такого мислителя, який би так відкрито та гнівно висловлювався проти християнської моралі як Ф. Ніцше. У праці «Антихрист» (прокляття християнству) dрiлософр різко критикував християнські церкви та усіх тих, котрі вважали себе християнами. Християнство нав'язуе людині уявний сенс, не даючи їй змоги віднайти справжній сенс, не ідеальний, а земний та реальний. Справжнє панування над усім земним, на думку Ніцше, полягає у запереченні ілюзорного потойбічного світу та вірі у земне щастя у цьому реальному світі.

Ніцше 3 острахом спостерігав картину тогочасного життя, закликаючи до внутрішнього бою душі. Захоплюючись новими відкриттями, вдосконаленням технічних засобів, люди не мають часу на душевні бесіди зі своїми близькими та друзями. Техніка, яку створює людина, пере- важно спрямована на перетворення ï на запрограмовану істоту 3 «технічним» складом душі та мислення. «Людина безмежна, і чекати від неї можна чого завгодно. Зло і добро вживаються в ній поряд» [5, с. 180]. Не менш важливим за значущістю поставлених питань $є$ твір Ніщше «Воля до влади». Вже сам підзаголовок: «Досвід переоцінки всіх цінностей» не залишає ніяких сумнівів, що це саме так. Вчення про волю є знаряддям для переоцінки цінностей. Особливий дар пророцтва Ніщше можна відчути, читаючи передмову. В основу книги лягла цілком конкретна історична ситуація. Ніцше поставив перед собою надзвичайно важливе завдання - здійснити прогноз, що визначатиме історію. Нігілізм був саме тією історичною ситуацією.

Висновки. Життя, на думку Ніщше, є чимось таким, що потрібно подолати. Філософр відчайдушно боровся 3 існуючим світом цінностей, що спричиняють занепад волі, життевої сили та знижують активність людини-творця. Хто дав право комусь розпоряджатись нашим життям, вказуючи якими нам потрібно бути, який шлях обрати? Хто надумав ці дивні норми моралі, що тісним кільцем оточують людину, не даючи їй вільно дихати, відбираючи у неї радість життя? А що можуть зробити 3 людиною такі «цінності» як: співчуття, докори сумління, жалість до слабшого? Вони зруйнують їі, позбавлять здорової сили, перекриють потік чудесних насолод і життевих інстинктів. Тож потрібно повстати проти старого життя в ім'я процвітання нового. Ніџше утікав від киплячого, пекельного життя якнайдалі від усіх i співав оди самотності. А, можливо, саме вона дала поштовх до роздумів, до геніальних ідей, далеко не утопічних, а цілком реальних, таких, щоб при бажанні можна було реалізувати. На думку А. Ейнштейна, людина не зможе жити з відчуттям відсутності сенсу у їі житті. I ніхто не дасть нам гарантій, що ці пошуки будуть легкими та позбавленими перешкод та розчарувань. Проте це буде наш шлях, наші прагнення, які допоможуть зрозуміти для чого ми прийшли у цей світ.

\section{Список літератури:}

1. Нищше Ф. Сочинения : в 2 т. / пер. с нем.; сост., ред. и авт. прим. К. А. Свасьян. Москва : Мысль, 1990. Т. 2.829 с.

2. Ницше Ф. Воля к власти: опыт переоценки всех ценностей. Москва : RELL-BOOK, 1994. 352 с.

3. Антонович И. Фридрих Ницше и традиции нигилизма в буржуазной культуре. Минск : Неман. 1982 . № 10. C. $127-136$.

4. Шумило Н. Гармонійне і дисгармонійне в українській літературі початку XX ст. : (Володимир Винниченко і сучасники). 1998. № 5. С. 124-131.

5. Кудрявцев Ю. Г. Три круга Достоевского. Москва, 1979. 343 с.

\section{References:}

1. Nietzsche F. (1990) Sochinenia: v 2 t. / per. s nem., sost., red. i avt. prim. K.A. Svasian [Essays]. Moscow: Musl, T. 2, 829 p. (in Russian)

2. Nietzsche F. (1994) Volya k vlasti: opyt pereotsenki vseh tsennostey [Will to power]. Moscow: RELL-BOOK. (in Russian)

3. Antonovych I. (1982) Friedrih Nietzsche i traditsii nigilizma v byrgyaznoi kyltyre [Friedrich Nietzsche and the traditions of nihilism in bourgeois culture]. Minsk: Neman, no. 10, pp. 127-136. (in Russian)

4. Shumylo N. (1998) Garmoniyne i disgarmoniyne v ukrainskiy literaturi pochatku XX st. [Harmonious and disharmonic in Ukrainian literature of the early twentieth century: (Volodymyr Vynnychenko and contemporaries]. Kyivska starovyna, no. 5, pp. 124-131. (in Ukrainian)

5. Kudryavtsev Y.H. (1979) Tri kruga Dostoevskogo [Three circles of Dostoevskiy]. Moscow, 343 p. (in Russian) 